\title{
EVALUATION OF SAMPLE PREPARATION METHODS AND OPTIMIZATION OF NICKEL DETERMINATION IN VEGETABLE TISSUES ${ }^{(1)}$
}

\author{
Rodrigo Fernando dos Santos Salazar ${ }^{(2)}$, Marco Aurélio Kondracki \\ de Alcântara ${ }^{(3)}$ \& Hélcio José Izário Filho ${ }^{(4)}$
}

\begin{abstract}
SUMMARY
Nickel, although essential to plants, may be toxic to plants and animals. It is mainly assimilated by food ingestion. However, information about the average levels of elements (including $\mathrm{Ni}$ ) in edible vegetables from different regions is still scarce in Brazil. The objectives of this study were to: (a) evaluate and optimize a method for preparation of vegetable tissue samples for Ni determination; (b) optimize the analytical procedures for determination by Flame Atomic Absorption Spectrometry (FAAS) and by Electrothermal Atomic Absorption (ETAAS) in vegetable samples and (c) determine the $\mathrm{Ni}$ concentration in vegetables consumed in the cities of Lorena and Taubaté in the Vale do Paraíba, State of São Paulo, Brazil. By means of the analytical technique for determination by ETAAS or FAAS, the results were validated by the test of analyte addition and recovery. The most viable method tested for quantification of this element was $\mathrm{HClO}_{4}-\mathrm{HNO}_{3}$ wet digestion. All samples but carrot tissue collected in Lorena contained Ni levels above the permitted by the Brazilian Ministry of Health. The most disturbing results, requiring more detailed studies, were the $\mathrm{Ni}$ concentrations measured in carrot samples from Taubaté, where levels were five times higher than permitted by Brazilian regulations.
\end{abstract}

Index-terms: trace elements, atomic absorption spectrometry, calcination, wet digestion, environmental pollution.

\footnotetext{
(1) Presented in two works on the XI Geochemistry Brazilian Congress. Granted by Fapesp (processes 57382-6 e 05/53056-7). Received for publication in March 2010 and approved in December 2010.

(2) Doctorate student at Department of Chemistry, Universidade Federal de São Carlos - UFSCAR, Rodovia Washington Luiz Km 235, Monjolinho, CEP 13565-905 São Carlos (SP). E-mail: r.f.s.salazar@gmail.com

(3) Professor at the Department of Biotechnology, Escola de Engenharia de Lorena. Universidade de São Paulo - USP. EstradaMunicipal do Campinho s/n ${ }^{\circ}$, Campus I, CEP 12602-810 Lorena (SP). E-mail: marko@usp.br

(4) Professor at the Departament of Chemistry Engeenering. Escola de Engenharia de Lorena. Universidade de São Paulo - USP. Lorena (SP), Brazil. E-mail: helcio@dequi.eel.usp.br
} 


\title{
RESUMO: AVALIAÇÃO DE MÉTODOS DE PREPARO DE AMOSTRA E OTIMIZAÇÃO DA DETERMINAÇÃO DE NÍQUEL EMTECIDOS VEGETAIS
}

\begin{abstract}
O Ni, embora essencial às plantas, pode ser tóxico a estas e aos animais. O hábito alimentar é geralmente a sua principal via de obtenção. Contudo, informações sobre a composição média de elementos (incluindo $\mathrm{Ni}$ ) em vegetais comestiveis em diferentes regiões ainda são escassas no Brasil. Os objetivos deste trabalho foram: (a) avaliar e otimizar um método para preparação de amostras de tecidos vegetais para a determinação de $\mathrm{Ni}$; (b) otimizar os procediemntos analíticos para a determinação por espectrometria de absorção atômica por chama (FAAS) e por aquecimento eletrotérmico (ETAAS) em amostras vegetais; $e$ (c) determinar a concentração de Ni em vegetais consumidos nas cidades de Lorena e Taubaté, no Vale do Paraíba, Estado de São Paulo, Brasil. Por meio da técnica analítica para determinação por ETAAS ou FAAS, os resultados puderam ser validados pelo teste de adição e recuperação de analito, sendo a digestão úmida com $\mathrm{HClO}_{4}-\mathrm{HNO}_{3}$ o método testado mais viável para quantificação desse elemento. Com exceção das amostras de cenoura coletadas em Lorena, todas as demais apresentaram teores de Ni acima do permitido pelo Ministério da Saúde do Brasil. Os resultados mais preocupantes e que demandam estudos mais detalhados referem-se aos teores de Ni nas amostras de cenoura da cidade de Taubaté, os quais foram superiores em cinco vezes aos limites estabelecidos pelas normas brasileiras.
\end{abstract}

\section{Termos de indexação: elementos-traço, espectrometria de absorção atômica, calcinação, digestão úmida, poluição ambiental.}

\section{INTRODUCTION}

Nickel is an element classified as essential to plants and, possibly, to animals (White \& Brown, 2010). This element participates in the structure of the metalloenzyme urease, responsible for the decomposition of urea to ammonium and $\mathrm{CO}_{2}$ (Dechen \& Nachtigall, 2006). On the other hand, this element may be toxic to plants and animals. According to White \& Brown (2010), the minimum foliar concentration and the toxicity range for this element are $0.1 \times 10^{-3}$ and 20 to $30 \times 10^{-3} \mathrm{mg} \mathrm{g}^{-1}$ dry matter, respectively. The phytotoxicity of $\mathrm{Ni}$ is a result of its action on the photosystem, causing disturbances in the Calvin cycle and inhibition of electrical transport because of the excessive quantities of ATP and NADPH accumulated by the inefficiency of dark reactions (Krupa et al., 1993). The element may be considered moderately toxic to the human metabolism in comparison to other transition metals and, according to Wittsiepe et al. (2009), the biological role of this element in human metabolism is not evident. When inhaled or ingested, it may lead to serious complications, including cancer of the respiratory system (Ferreira et al., 2001; O'Neil et al., 2001).

Food ingestion is generally the main means of metal uptake. Nevertheless, information on the average composition of elements (including $\mathrm{Ni}$ ) in edible vegetables from different regions is still scarce in Brazil (Kawashima \& Soares, 2003; Santos et al., 2004). In several studies, as of Rocha et al. (2003) and Trannin et al. (2005), Ni concentrations (among other metals) in plants resulting from the addition of residues to the soil were determined. In the literature, studies as conducted by Schmidt et al. (2009) are rare, monitoring different metal contents in plants grown on soils in relation to the material of origin of a region (basalt and Caiuá sandstone). According to the Agency for Toxic Substance \& Disease Registry (ATSDR), the estimated daily tolerable dosage of $\mathrm{Ni}$ for adults of $70 \mathrm{~kg}$ is $0.001-0.0024 \mathrm{mg} \mathrm{kg}^{-1}$ day $^{-1}$ (ATSDR, 2010). Between 5 and $40 \%$ of Ni present in foods is absorbed by the digestive tract, while, when inhaled, absorption oscillates from around 20 to $35 \%$ (ATSDR, 2010). Data on metal concentrations in foods are therefore important and can provide basic information regarding the impacts caused by chemical products, effluents and residues used for crop maintenance and determine the levels of environmental pollution on family farms and agroindustrial farms. In the region of the Vale do Paraíba do Sul (in Taubaté, SP), contamination of maternal colostrum by Cd (Nascimento et al., 2005) and by $\mathrm{Pb}$ (Nascimento et al., 2006) has been detected recently in studies. In both studies, the authors warn that the possible sources of these metals must be identified.

Among the diverse methods for determination of minerals in vegetables, spectrometric techniques are among the most commonly used, due to their sensitivity and selectivity. The most widespread tool used with this technique is Flame Atomic Absorption Spectrometry (FAAS), produced by combustion of a mixture of air/acetylene or nitrous oxide/acetylene. An alternative to the use of FAAS, when the determination of a metal at the ultra trace level $\left(\mu \mathrm{g} \mathrm{kg}^{-1}\right)$ is desired, is the electrothermal atomic absorption spectrometry technique (ETAAS), in which a graphite oven substitutes the flame as atomization 
source. Generally the detection limit for ETAAS is three times lower than by flame atomization (Izário Filho, 1999). It is worth remembering that aside from the spectrometric techniques, it is possible to determine various metals (including $\mathrm{Ni}$ ) by other methods. An example of a study in this sense was undertaken by Yang et al. (2005), who developed a method for determining $\mathrm{Pb}, \mathrm{Cd}, \mathrm{Hg}, \mathrm{Ni}$ and $\mathrm{Zn}$ by high-efficiency liquid chromatography.

As important as the instrumentation is the pretreatment stage of the sample. This stage is fundamental for reliable results, as well as optimization of the technique and method to be used, so as to reduce the time and cost of analyses, as well as to increase the degree of reliability of the results (Izário Filho, 1999). According to Wieteska et al. (1996) plant tissues are constantly used as bioindicators of the degree of pollution caused by a certain element to the environment. The introduction of new, ever-more effective techniques for the analysis of elements at trace levels which are simple and rapid comes to meet the growing need for control and monitoring of the disposal of inorganic compounds that cause harm to the environment and to human health (Ferreira et al., 2001). Along with the greater need for environmental control, the demand for legislation and inspection for analysis of trace elements also increases. In the case of $\mathrm{Ni}$, the concern is pertinent since this element is mostly absorbed via food consumption, leading to harmful effects on human health (O'Neil et al., 2001; Wittsiepe et al., 2009; ATSDR, 2010).

The objectives of this study were to: (a) evaluate and optimize a method for preparation of vegetable tissue samples for Ni determination; (b) optimize the analytical procedures for determination by Flame Atomic Absorption Spectrometry (FAAS) and by Electrothermal Atomic Absorption (ETAAS) in vegetable samples and (c) determine Ni concentration in vegetables commonly consumed in the cities of Lorena and Taubaté in the Vale do Paraíba, state of São Paulo, Brazil.

\section{Sample collection and preparation}

Samples of lettuce, potato, beet, carrot and manioc were acquired on fruit and vegetable markets and from greengrocers four times in the period from August 2006 to March 2007 in the commercial area of two cities of the Vale do Paraíba, SP - Taubaté and Lorena. For each collection, two samples of each vegetable type were collected, one in each city. There was a total of 40 samples, eight samples of each type. For the tuberous vegetables, only roots and peels were acquired. In the case of leafy vegetables (lettuce), the leaves and stalk were acquired. All samples appeared suitable for human consumption and had no signs of rotting.

In the sample pretreatment, modified procedures for washing and drying proposed by Santos et al. (2004) and Kawashima \& Soares (2003), respectively, were used. First, each plant sample was rinsed with distilled water to remove dirt and other debris. Then the vegetables were brushed with polypropylene bristles and washed with deionized water. The samples of the above-ground part of the lettuce were carefully cut with the stalks of each leaf, with the exception of the center stalk, which was discarded along with the roots. The samples of the underground parts of potato, beet, carrot and manioc were grated with a polypropylene grater into porcelain containers. Then the containers with the samples were dried in a laboratory oven at $65 \pm 5^{\circ} \mathrm{C}$ for $24 \mathrm{~h}$ or until reaching constant weight. Immediately afterwards, the samples were stocked in polypropylene beakers and covered with a PVC film. Finally, they were stored in a desiccator. For moisture determination, a $1.0 \pm$ $0.1 \mathrm{mg}$ portion of the sample was used, according to the method described by Bianchi (1995). For each dehydrated sample analyzed, calculations were made to know how much of the weight of the corresponding fresh sample this sample represented (Equation 1):

$$
M_{f}=\frac{\left(100 \times M_{S}\right)}{(100-\text { Umid })}
$$

where $M_{f}$ represents the fresh sample mass (g), $M_{s}$ the weighed dried sample mass (g) and Umid the mean moisture percentage of the sample. With the values of the FAAS and ETAAS analyses for $\mathrm{Ni}$ and $M_{f}$, the metal mass per fresh sample mass was calculated by equation 2:

$$
m=\left(\frac{C}{M_{f}}\right) \times f
$$

in which $m$ represents concentration of the metal per fresh sample mass $\left(\mathrm{mg} \mathrm{kg}^{-1}\right.$ or $\left.\mu \mathrm{g} \mathrm{kg}^{-1}\right), C$ the metal concentration in the solution $\left(\mathrm{mg} \mathrm{L}^{-1}\right), M_{f}$ the fresh sample mass (g) and $f$ the unit conversion factor (in this case, $f=1000)$.

\section{Analyte dissolution}

Nickel was determined using modified procedures of Wieteska et al. (1996) to prepare vegetable samples via acid digestion and calcination, for later determination by FAAS or ETAAS. Analyte addition and recovery tests were performed adding $1.5 \mathrm{mg}$ of $\mathrm{Ni}$ standard to $0.5 \mathrm{~g}$ of dehydrated beet and manioc samples (equivalent to $30 \mathrm{mg} \mathrm{kg}^{-1}$ dry matter basis) for later determination in FAAS. In the dehydrated samples of lettuce, potatoes and carrots, $250 \mathrm{pg} \mathrm{Ni}$ was added to $0.5 \mathrm{~g}$ sample for the addition and recovery test by ETAAS (equivalent to $500 \mu \mathrm{g} \mathrm{kg}{ }^{-1}$, dry matter basis).

CALCINATION: First, dehydrated samples of approximately $0.5 \mathrm{~g}$ of each plant were filled in porcelain crucibles and covered for calcination. The crucibles were transferred to a muffle furnace and exposed to a heating $\mathrm{ramp}\left(100\right.$ to $\left.500{ }^{\circ} \mathrm{C}\right)$ in 
temperature intervals of $100{ }^{\circ} \mathrm{C}$ maintained for 20 min. Finally, the maximum temperature of $500^{\circ} \mathrm{C}$ was maintained for $2 \mathrm{~h}$. The calcination residues were digested with $2.0 \mathrm{~mL}$ of deionized $\mathrm{H}_{2} \mathrm{O}$, and $0.5 \mathrm{~mL}$ of $\mathrm{HCl}$ and $1.0 \mathrm{~mL}$ of $\mathrm{HNO}_{3}$, both concentrated. The crucibles were covered with watch glass and heated on a hotplate for $30 \mathrm{~min}$, in a sand bath. This ensured a better control of heat and reflux, avoiding drift and evaporation loss completely, as well as the formation of metallic oxides of the elements of interest and ensuring complete digestion. After digestion and cooling, the entire digestion system was adequately rinsed with deionized water, the solutions of the crucibles were quantitatively transferred to $50.0 \mathrm{~mL}$ volumetric flasks and completed with deionized $\mathrm{H}_{2} \mathrm{O}$.

ACID DIGESTION: $0.5 \mathrm{~g}$ of each dehydrated sample was filled in $50 \mathrm{~mL}$ glass beakers. Then, $5.0 \mathrm{~mL}$ of an acid mixture composed of $\mathrm{HNO}_{3}$ and $\mathrm{HClO}_{4}(4: 1 \mathrm{v} / \mathrm{v})$ and $2.0 \mathrm{~mL}$ of deionized $\mathrm{H}_{2} \mathrm{O}$ was pipetted into each beaker. Each beaker was covered with watch glass and transferred to a sand bath for a mild digestion, an important procedure when working with this type of acid mixture. Digestion time varied from 1 to $2 \mathrm{~h}$, under continuous reflux of the solution of the system, to let the digestion product become as clear as possible (Wieteska et al., 1996). After digestion and cooling, the solutions of the crucibles were quantitatively transferred to $50.0 \mathrm{~mL}$ flasks and completed with deionized $\mathrm{H}_{2} \mathrm{O}$.

The metal concentration in the plant samples was determined after dissolution using a Perkin-Elmer, model AAnalyst 800 atomic absorption spectrometer. The FAAS system with air $/ \mathrm{C}_{2} \mathrm{H}_{2}$ flow was used to determine the metals in the samples of beets (Beta vulgaris L.), carrots (Daucus carota L.) and manioc (Manihot utilissima L.) and ETAAS for the samples of lettuce (Lactuva sativa L.) and potato (Solanum tuberosum L.). The experimental conditions are described in table 1.

\section{Method optimization and validation}

The method was optimized based on the pyrolysis and atomization curves for carrot samples, obtained according to the procedure described for analyte dissolution. For validation of the calcination and acid digestion methods, the addition and recovery test for

Table 1. Tolerable Ni concentrations (in mg kg-1) in fresh matter, in accordance with standards of the Ministry of Health

\begin{tabular}{lc}
\hline Vegetables & Tolerable concentration $^{(1)}$ \\
\hline & $\mu \mathrm{g} \mathrm{kg}^{-1}$ \\
Lettuce & 26 \\
Potatoes & 13 \\
Carrots & 38 \\
Manioc & 260 \\
\hline
\end{tabular}

(1) According to Santos et al. (2004). the $\mathrm{Ni}$ was used in the vegetable tissue samples due to the nonexistence of certified standards for the vegetable tissues studied according to the National Institute of Standards and Technology - NIST, 110.4 Agricultural Materials, in powder form (NIST, 2006). In the validation, the characteristic mass value and experimental detection limit were considered.

The characteristic mass value $\left(m_{0}\right)$, which expresses the sensitivity of an analytical determination, is given by equation (3) (Izário Filho, 1999):

$$
m_{0}=\frac{\text { (quantityinjected } \mathrm{x} \text { analyteconcentration } \mathrm{x} 0.0044)}{(\text { signalmeasured } \mathrm{x}(\text { analyte }- \text { blank }))}
$$

where the injected quantity is expressed in $\mathrm{mL}$, the concentration in $\mathrm{mg} \mathrm{L}^{-1}$ and the signal measured is the area under the curve.

Another procedure to express the sensitivity of an analytical determination is the value of the instrumental detection limit (IDL) of the elements in the diverse electrothermal systems. The $I D L$ is defined by the baseline noise and the measurement sensitivity according to equation 4 (Izário Filho, 1999):

$$
I D L=\frac{\left(3 \times s_{b r} \times m_{0}\right)}{0.0044}
$$

in which $s_{b r}$ is the standard deviation of the blank signal.

\section{Nickel concentrations in vegetables consumed in Taubaté and Lorena}

By the method optimized in this study (acid digestion), the $\mathrm{Ni}$ concentration in vegetable tissues commonly consumed in Taubaté and Lorena was determined using IBGE data from (IBGE, 2006), relating the metal concentration with the limits determined by Portaria 685 (Administrative Directive 685) of the Sanitary Inspection Office of the Ministry of Health (Secretaria de Vigilância Sanitária do Ministério da Saúde) as reported by Santos et al. (2004) (Table 2). The concentrations were determined for fresh matter, as foreseen in the above directive.

Table 2. Experimental conditions (EC) for metal determination by atomic absorption spectrometry with flame atomization and graphite oven for calcination and acid digestion

\begin{tabular}{lc}
\hline \multicolumn{1}{c}{ EC } & Value \\
\hline Wave Length $(\mathrm{nm})$ & 232.0 \\
Opening of the Slit $(\mathrm{nm})$ & 0.20 \\
Bulb Current $(\mathrm{mA})$ & 25 \\
Pyrolysis Temperature $\left({ }^{\circ} \mathrm{C}\right)$ & 1600 \\
Atomization Temperature $\left({ }^{\circ} \mathrm{C}\right)$ & 2500 \\
Air/acetylene $\left(\mathrm{L} \mathrm{min}{ }^{-1}\right)$ & $17.0 / 2.0$ \\
\hline
\end{tabular}




\section{RESULTS AND DISCUSSION}

\section{Moisture of vegetable samples}

The method used for determination of moisture proved to be viable since the repeatability was significant, ranging from $0.04 \%$ for beet to $2.06 \%$ for potato samples (Table 3). These experimentally obtained average moisture values were used for determination of the metal mass per fresh sample mass.

Table 3. Average percentage of water (moisture) in fresh plants

\begin{tabular}{lc}
\hline Vegetables & Moisture \\
\hline Lettuce & $\%$ \\
Potatoes & $94.28 \pm 0.32$ \\
Beets & $83.59 \pm 1.89$ \\
Carrots & $88.73 \pm 0.04$ \\
Manioc & $87.96 \pm 0.26$ \\
& $59.29 \pm 0.44$ \\
\hline
\end{tabular}

\section{Optimization and validation of the analytical methods}

From the pyrolysis and atomization curves (Figure 1), it was possible to determine the best temperature related to these stages, ensuring a symmetric and representative atomization signal for the analyte mass. These data also permitted better programming for analysis via ETAAS. The characteristic mass $\left(\mathrm{m}_{0}\right)$ values for calcination, calculated by equation (3), oscillated from $19.4 \mathrm{pg} \mathrm{s}^{-1}$ in carrot to $134.7 \mathrm{pg} \mathrm{s}^{-1}$ in potato samples. For the acid digestion method, $\mathrm{m}_{0}$ ranged from $37.3 \mathrm{pg} \mathrm{s}^{-1}$ in potato to $100.3 \mathrm{pg} \mathrm{s}^{-1}$ in carrot. Table 4 presents the optimized conditions for determination of Ni by ETAAS in terms of the digestion used.

The first tests evaluating calcination in the proposed period of $4 \mathrm{~h}$ were insufficient for a complete dry digestion of the manioc and beet samples. The ashes had to be digested with a mixture of $\mathrm{HCl}+$ $\mathrm{HNO}_{3}$ to ensure complete digestion of the matrix and solubilization of the analyte of interest. The need for a second digestion stage after calcination was observed by Wieteska et al. (1996) in the development of digestion procedures in an open system for lignocellulosic matrices. Even presenting a reasonable analytical frequency due to the $2^{\text {nd }}$ digestion step, the calcination method proposed presents better analytical frequency than the dry digestion method proposed by Wieteska et al. (1996) and by Santos et al. (2004), who proposed a method for sample preparation via calcination for $24 \mathrm{~h}$.

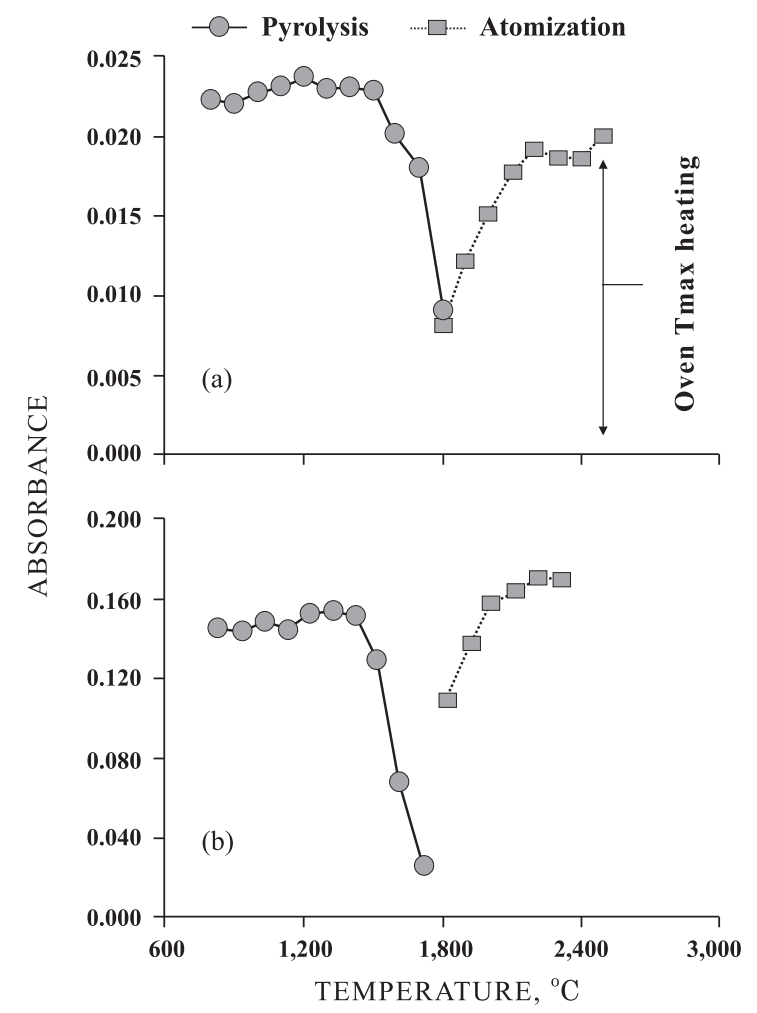

Figure 1. Atomization and pyrolysis curves in carrots: (a) acid digestion and addition of $50 \mathrm{pg} \mathrm{Ni}$ and (b) calcination and addition of $400 \mathrm{pg} \mathrm{Ni}$.

Table 4. Optimization of the atomization and pyrolysis temperatures for $\mathrm{Ni}$ determination by ETAAS

\begin{tabular}{|c|c|c|c|c|}
\hline \multirow{2}{*}{ Vegetable } & \multicolumn{2}{|c|}{ Calcination } & \multicolumn{2}{|c|}{ Acid Digestion } \\
\hline & Pyrolysis & Atomization & \multicolumn{2}{|c|}{ Pyrolysis Atomization } \\
\hline & & & \multicolumn{2}{|c|}{${ }^{\circ} \mathrm{C}$} \\
\hline Lettuce & 1330 & 2300 & 1500 & 2100 \\
\hline Potatoes & 1500 & 2400 & 1600 & 2500 \\
\hline Carrots & 1300 & 2200 & 1200 & 2500 \\
\hline
\end{tabular}

Regardless of the method, it was found that the instrumental limit (IDL) calculated by equation (4) varied from 1.7 to $8.1 \mathrm{pg}$. For the samples analyzed via FAAS, it was found that the experimental detection limit varied from $0.117 \mathrm{mg} \mathrm{L}^{-1}$ in manioc by acid digestion, to $0.152 \mathrm{mg} \mathrm{L}^{-1}$ in beet by the calcination method. The detection limit of the ETAAS technique was $0.140 \mu \mathrm{g} \mathrm{L}^{-1}$. It was observed that the procedures optimized for acid digestion were greater than the those optimized for calcination in most vegetables analyzed, possibly due to greater interference of the matrix with the chemical reagents.

\section{Validation of the methods}

After optimization of the procedures, $\mathrm{Ni}$ addition and recovery was tested with each sample type, also 
verifying the influence of the method used on the analyte recovery percentages. High recovery of the two Ni analysis methods by ETAAS and FAAS was observed, except in manioc samples by calcination (Table 5). The percentages of recovered analyte oscillated from 87.8 to $119.9 \%$ by acid digestion and from 88.3 to $110.0 \%$ by calcination, with the exception of $\mathrm{Ni}$ determination in manioc via calcination (64.8\%), possibly due to an incomplete digestion of this matrix. According to Krug \& Nóbrega (Krug, 2008), a high residual C content, together with incomplete digestion of certain organic matrices, may lead to errors in precision and accuracy of the method chosen due to possible complexes formed between the analyte and the matrix. Consequently, the nonatomization of the analyte and effects of molecular absorption of the matriz during determination by spectrometric techniques due to incomplete digestion affect the results in terms of repeatability and reproducibility even more (Krug, 2008). With the exception of the manioc samples via calcination, the values may be considered analytically satisfactory for both methods, making an application of the method in the analytical $\mathrm{Ni}$ determinations viable in the samples of interest.

It is important to emphasize that this study does not intend to criticize other methods used for $\mathrm{Ni}$ analysis in vegetable samples, but simply to show that the methods tested are adequate for the quantification of this element. The tested methods represent an alternative procedure for laboratories where analytical determination methods of elements are required but there is a lack of automated sample digestion systems such as closed decomposition systems complemented by microwaves or of decomposition systems with focalized microwave radiation, in which the consumption of reagents may be more elevated than in the methods proposed in this study.

\section{Nickel concentrations in the vegetables consumed in Taubaté and Lorena}

For the analysis of real samples, a graph was drawn to compare the values obtained in the municipalities of Taubaté and Lorena. The Ni concentrations were reported in micrograms of the element per plant fresh matter $\left(\mu \mathrm{g} \mathrm{kg}^{-1}\right)$. The $\mathrm{Ni}$ contents in roots (potatoes and beets) of Lorena were of the same order of magnitude $\left(50.5 \pm 3.2 \mu \mathrm{g} \mathrm{kg}^{-1}\right.$, $8.3 \pm 1.2 \mathrm{mg} \mathrm{kg}^{-1}$, respectively) as in the samples from Taubaté $\left(34.3 \pm 5.5 \mu \mathrm{g} \mathrm{kg}^{-1}, 9.9 \pm 1.6 \mathrm{mg} \mathrm{kg}^{-1}\right.$, respectively) (Table 6). In lettuce samples (103.0 \pm $\left.17.7 \mu \mathrm{g} \mathrm{kg}^{-1}\right) \mathrm{Ni}$ concentrations were around twice as high in samples from Taubaté than from Lorena (49.0 $\left.\pm 6.1 \mu \mathrm{g} \mathrm{kg}^{-1}\right)$. For carrot fresh matter, it was observed that concentrations in samples from Taubaté (230.0 $\pm 20.0 \mu \mathrm{g} \mathrm{kg}^{-1}$ ) were around 10 times higher than from Lorena $\left(22.3 \pm 5.0 \mu \mathrm{g} \mathrm{kg}^{-1}\right)$.

Table 5. Percentage of $\mathrm{Ni}$ recovery in the analyte addition and recovery tests

\begin{tabular}{|c|c|c|c|c|c|c|c|}
\hline \multirow{2}{*}{ Vegetable } & \multirow{2}{*}{ Sample } & \multicolumn{3}{|c|}{ Calcination, $500^{\circ} \mathrm{C}$} & \multicolumn{3}{|c|}{ Acid digestion } \\
\hline & & \multicolumn{2}{|c|}{ Ni added } & $\begin{array}{c}\% \text { recovery } \\
\text { Mean } \pm \text { Deviation }\end{array}$ & \multicolumn{2}{|c|}{$\mathrm{Ni}$ added } & \multirow{2}{*}{$\begin{array}{c}\% \text { recovery } \\
\text { Mean } \pm \text { Deviation }\end{array}$} \\
\hline \multirow[t]{3}{*}{ Lettuce } & & 0.0 & $\left(500+53.0 \mu \mathrm{g} \mathrm{kg}^{-1}\right)$ & & 0.0 & $\left(500+53.0 \mu \mathrm{g} \mathrm{kg}^{-1}\right)$ & \\
\hline & $\begin{array}{l}\text { (A) } \\
\text { (B) } \\
\text { (C) }\end{array}$ & $\begin{array}{l}55.2 \\
58.3 \\
51.5 \\
65.1\end{array}$ & $\begin{array}{l}595.2 \\
645.3 \\
521.0 \\
565.1\end{array}$ & $110.0 \pm 11.7$ & $\begin{array}{l}53.9 \\
52.3 \\
55.1 \\
57.4\end{array}$ & $\begin{array}{l}597.2 \\
552.3 \\
546.4 \\
557.4\end{array}$ & $103.4 \pm 4.6$ \\
\hline & & 0.0 & $\left(30+42.5 \mathrm{mg} \mathrm{kg}^{-1}\right)$ & & 0.0 & $\left(30+42.5 \mathrm{mg} \mathrm{kg}^{-1}\right)$ & \\
\hline \multirow[t]{2}{*}{ Beets } & $\begin{array}{l}\text { (A) } \\
\text { (B) } \\
\text { (C) } \\
\text { (D) }\end{array}$ & $\begin{array}{l}41.6 \\
39.6 \\
40.8 \\
37.2\end{array}$ & $\begin{array}{l}61.6 \\
65.6 \\
68.1 \\
60.0\end{array}$ & $88.3 \pm 5.6$ & $\begin{array}{l}35.2 \\
35.4 \\
35.4 \\
35.6\end{array}$ & $\begin{array}{l}61.8 \\
62.5 \\
62.4 \\
61.7\end{array}$ & $88.5 \pm 0.6$ \\
\hline & & 0.0 & $\left(500+40.0 \mu \mathrm{g} \mathrm{kg}^{-1}\right)$ & & 0.0 & $\left(500+40.0 \mu \mathrm{g} \mathrm{kg}^{-1}\right)$ & \\
\hline \multirow[t]{2}{*}{ Potatoes } & $\begin{array}{l}\text { (A) } \\
\text { (B) } \\
\text { (C) }\end{array}$ & $\begin{array}{l}42.1 \\
40.6 \\
41.3 \\
43.5\end{array}$ & $\begin{array}{l}549.1 \\
586.4 \\
567.3 \\
548.6\end{array}$ & $105.1 \pm 3.5$ & $\begin{array}{l}39.6 \\
41.5 \\
45.3 \\
42.4\end{array}$ & $\begin{array}{l}609.7 \\
573.5 \\
545.3 \\
536.2\end{array}$ & $106.1 \pm 6.8$ \\
\hline & & 0.0 & $\left(500+40.0 \mu \mathrm{g} \mathrm{kg}^{-1}\right)$ & & 0.0 & $\left(500+40.0 \mu \mathrm{g} \mathrm{kg}^{-1}\right)$ & \\
\hline \multirow[t]{2}{*}{ Carrots } & $\begin{array}{l}\text { (A) } \\
\text { (B) } \\
\text { (C) } \\
\text { (D) }\end{array}$ & $\begin{array}{l}41.9 \\
40.3 \\
43.9 \\
42.5\end{array}$ & $\begin{array}{l}544.9 \\
574.3 \\
591.3 \\
552.5\end{array}$ & $105.2 \pm 4.3$ & $\begin{array}{l}72.3 \\
77.3 \\
75.7 \\
76.1\end{array}$ & $\begin{array}{l}655.3 \\
677.3 \\
675.7 \\
692.4\end{array}$ & $119.9 \pm 3.3$ \\
\hline & & 0.0 & $\left(30+38.4 \mathrm{mg} \mathrm{kg}^{-1}\right)$ & & 0.0 & $\left(30+38.4 \mathrm{mg} \mathrm{kg}^{-1}\right)$ & \\
\hline Manioc & $\begin{array}{l}\text { (A) } \\
\text { (B) } \\
\text { (C) } \\
\text { (D) }\end{array}$ & $\begin{array}{l}23.4 \\
27.6 \\
24.1 \\
22.2\end{array}$ & $\begin{array}{l}36.9 \\
51.7 \\
44.1 \\
48.2\end{array}$ & $64.8 \pm 10.8$ & $\begin{array}{l}33.7 \\
34.2 \\
35.6 \\
31.8\end{array}$ & $\begin{array}{l}56.2 \\
60.2 \\
63.9 \\
61.8\end{array}$ & $87.8 \pm 5.6$ \\
\hline
\end{tabular}


Table 6. Comparison between Ni concentration values and fresh mass of plants consumed in Lorena and Taubaté

\begin{tabular}{lcc}
\hline Vegetables & Taubaté & Lorena \\
\hline & & \\
\cline { 2 - 3 } & & \\
Lettuce & $103.7 \pm 17.7$ & $49.0 \pm 6.1$ \\
Potatoes & $34.3 \pm 5.5$ & $50.5 \pm 3.2$ \\
Beets & $9932.1 \pm 1614.4$ & $8344.6 \pm 1246.3$ \\
Carrots & $232.4 \pm 22.3$ & $22.3 \pm 5.0$ \\
Manioc & $376.2 \pm 26.1$ & $11825.1 \pm 893.1$ \\
\hline
\end{tabular}

In a comparison of the results (Table 6) with the legal tolerance limits (Table 1), it was found that with exception of the carrot samples from Lorena, the levels exceeded the permitted. This was mainly true for the carrot samples in which Ni concentrations were more than five times greater than in samples from Taubaté. Some hypotheses may be suggested to explain this fact. It is possible that the means of contamination of the plants occurred through the air or the water used for the crops. It is also possible that the contamination was due to the use of urea fertilizers enriched with $\mathrm{Ni}$ to stimulate uptake by the vegetables (Dechen \& Nachtigall, 2006). Another possibility would be the use of Ni-containing sewage sludge, which may have elevated Ni concentrations, as observed similarly by Revoredo \& Melo (2006) in sorghum plants.

\section{CONCLUSIONS}

1. The analytical techniques for determination by ETAAS or FAAS could be validated by the analyte addition and recovery test. Both dry and wet digestion with $\mathrm{HClO}_{4}-\mathrm{HNO}_{3}$ proved to be viable for $\mathrm{Ni}$ quantification, serving as an alternative procedure in laboratories that need analytical methods for determination of elements and that lack automated sample digestion systems.

2 . With the exception of carrot samples from Lorena, the Ni concentrations of all other plants investigated in this study exceeded the permitted by Brazilian legislation and.

3. The most alarming results, which call for more detailed studies, are the Ni concentrations in carrot samples from Taubaté, where levels were five times higher than determined by Brazilian regulations.

\section{ACKNOWLEDGEMENTS}

The authors gratefully acknowledge the financial support (Process no. 05/57382-6 and 05/53056-7) of the Research Support Foundation of the State of São Paulo (Fundação de Amparo à Pesquisa do Estado de São Paulo - FAPESP).

\section{LITERATURE CITED}

AGENCY FOR TOXIC SUBSTANCES \& DISEASE REGISTRY - ATSDR. Nickel: Toxicological profile. 2010. Disponível em:http://www.atsdr.cdc.gov/ToxProfiles/ TP.asp?id=245\&tid=44 . Accessed on August 12, 2010

BIANCHI, M.L. Polpação de palha de milho utilizando-se diferentes processos organosolv. Campinas, Universidade Estadual de Campinas, 1995. (Tese de Mestrado)

DECHEN, A.R. \& NACHTIGALL, G.R. Micronutrientes. In: FERNANDES, M.S., ed. Nutrição mineral de plantas. Viçosa, MG, Sociedade Brasileira de Ciência do Solo, 2006. p.327-354.

FERREIRA, S.L.C.; SANTOS, W.N.L. \& LEMOS, V.A. Online preconcentration system for nickel determination in food samples by flame atomic absorption spectrometry. Anal. Chim. Acta, 445:145-151, 2001.

IBGE: Instituto Brasileiro de Geografia e Estatística. Ministério do Planejamento, Orçamento e Gestão. Produção agrícola municipal. 2006. Disponível em: <http:// ww w. sidra.ibge.gov.br/b d a / t a bela/ listabl.asp?c=1612\&z=p\&o=22>. Acesso em 30 abr. 2006.

IZÁRIO FILHO, H. Determinação de Co, Cu, Fe, Mn e Mo em tântalo com alta pureza usando espectrometria por absorção atômica em forno de grafite. Campinas, Universidade Estadual de Campinas, 1999. 171p. (Tese de Doutorado)

KAWASHIMA, L.M. \& SOARES, L.M.V. Mineral profile of raw and cooked leafy vegetables consumed in Southern Brazil. J. Food Composition Anal., 16:605-611, 2003.

KRUG, F.J. \& NÓBREGA, J.A. A sequência analítica. In: KRUG, F.J., ed. Métodos de preparo de amostras: Fundamentos sobre prepare de amostras orgâncias e inorgânicas para análise elementar. Piracicaba, CENA/ USP, 2008. p.13-58.

KRUPA, Z.; SIEDLECKA, A.; MAKSYMIEC, W. \& BASZYNSKI, Y.T. In vivo response of photosynthetic apparatus of Phaseolus vulgaris L. to nickel toxicity. Journal of Plant Physiology, 142:664-668, 1993.

NASCIMENTO, L.F.C.; IZARIO FILHO, H.J.; PEREIRA, M.L. \& BACCAN, N. Cadmium quantification in Brazilian mothers colostrum: A regional study. R. Bras. Saúde Materno Infantil, 5:193-198, 2005.

NASCIMENTO, L.F.C.; IZARIO FILHO, H.J. \& BALTAZAR, E.O. Níveis de chumbo em colostro humano: Um estudo no Vale do Paraíba. R. Bras. Saúde Materno Infantil, 6:p.69-74, 2006.

NATIONAL INSTITUTE OF STANDARDS AND TECHNOLOGY - NIST. Technology Services: Standard Reference Materials. 2006. Disponível em: <https:// srmors.nist.gov/tables/view_table.cfm?table $=110-4 . \mathrm{htm}>$. Accessed on August 1, 2006. 
O'NEIL, J.M.; SMITH, A.; HECKELMAN, P.E.; OBENCHAIN Jr, J.R.; GALLIPEAU, J.A.R.; D'ARECCA, M.A. \& BUDAVARI, S., eds. The Merck Index - An encyclopedia of chemicals, drugs and biologicals. 13.ed. Whitehouse Station, Merck \& Co, 2001. p.1165.

ROCHA, R.E.M.; PIMENTEL, M.S.; ZAGO, V.C.P.; RUMJANEK, N.G. \& DE-POLLI, H. Avaliação de biossólido de águas servidas domiciliares como adubo em couve . Pesq. Agropec. Bras., 38:1435-1441, 2003.

REVOREDO, M.D. \& MELO, W.J. Disponibilidade de níquel em solo tratado com lodo de esgoto e cultivado com sorgo. Bragantia, 65:679-685, 2006

SANTOS, E.E.; LAURIA, D.C.\& PORTO DA SILVEIRA, C.L. Assessment of daily intake of trace elements due to consumption of foodstuffs by adult inhabitants of Rio de Janeiro city. Sci. Total Environ., 327:69-79, 2004.

SCHMIDT, C.A.P.; MIGLIORANZA, É.; NAGASHIMA, G. \& GRECCO, F. Concentrações de metais pesados em grãos de café produzidos em lavouras sobre solos originados do basalto e do arenito Caiuá. Ci. Rural [online]. 2009. Available at: <http://www.scielo.br/ scielo.php?script=sci_pdf\&pid=S0103. $84782009005000100 \& \operatorname{lng}=\mathrm{en} \& \mathrm{nrm}=\mathrm{i}$ so\&tlng=pt $>$. Accessed on: June 16, 2009.
TRANNIN, I.C.B.; SIQUEIRA, J.O. \& MOREIRA, F.M.S. Avaliação agronômica de um biossólido industrial para a cultura do milho . Pesq. Agropec. Bras., 40:261-269, 2005.

WIETESKA, E.; ZIÓEK, A. \& DRZEWIÑSKA, A. Extraction as a method for preparation of vegetable samples for the determination of trace metals by atomic absorption spectrometry. Anal. Chimica Acta, 330:251-257, 1996.

WITTSIEPE, J.; SCHNELL, K.; HILBIG, A.; SCHREY, P.; KERSTING, M. \& WILHELM, M. Nutrition: Dietary intake of nickel and zinc by young children - Results from food duplicate portion measurements in comparison to data calculated from dietary records and available data on levels in food groups. J. Trace Elements Medic. Biol., 23:183-194, 2009.

WHITE, P.J. \& BROWN, P.H. Plant nutrition for suistenable development and global health. Annals of Botany, v.105, p.1073-1080, 2010 .

YANG, G.; HU, Q.; HUANG, Z. \& YIN, J. Study on the determination of lead, cadmium, mercury, nickel and zinc by a rapid column high-performance liquid chromatography. J. Braz. Chem. Soc., 16:1154-1159, 2005. 